\title{
Combination of anatomical locking plate and retrograde intramedullary nail in distal femoral fractures: comparison of mechanical stability
}

\author{
Distal femur kırıklarında anatomik kilitli plak ile retrograd intramedüller çivi kombinasyonu: \\ Mekanik stabilitenin karşılaşııılması
}

\author{
Onur Başcı, MD., ${ }^{1}$ Ahmet Karakaşlı, MD., ${ }^{1}$ Erdem Kumtepe, MSc., ${ }^{2}$ \\ Ortaç Güran, MD., ${ }^{1}$ Hasan Havıtçıoğlu, MD. ${ }^{1}$ \\ 'Department of Orthopedics and Traumatology, Medical Faculty of Dokuz Eylül University, İzmir, Turkey \\ ${ }^{2}$ Department of Biomechanics, Dokuz Eylul University Institute of Health Sciences, İzmir, Turkey
}

\begin{abstract}
Objectives: This study aims is to investigate mechanical properties of intramedullary (IM) nailing and anatomical locking plate in a bone model based on the hypothesis that their combined usage increases safety of fixation stabilization.

Materials and methods: Twenty-one left distal femoral fracture models were used in the study. Bones were divided into three equal groups. Group 1 specimens were fixed laterally by distal femoral anatomical locking plate. Group 2 specimens were fixed with retrograde distal femoral IM nail. Group 3 specimens were fixed with both distal femoral anatomical locking plate and retrograde distal femoral IM nail. In mechanical tests, alterations in axial loading, torsion angles, and load to failure values were measured and compared between groups.

Results: Compared to group 1, group 2 was relatively more resistant in axial load tests $(p=0.225)$, and significantly more resistant in load to failure tests $(\mathrm{p}=0.048)$. Group 1 was relatively more resistant in torsional load tests $(\mathrm{p}=0.949)$ compared to group 2 . Group 3 was significantly more resistant than group 1 in axial $(p=0.001)$, torsional $(p=0.012)$ load tests and load to failure tests $(\mathrm{p}=0.008)$. Group 3 was significantly more resistant compared to group 2 in axial $(p=0.003)$, torsional $(\mathrm{p}=0.008)$ load tests, and relatively more resistant $(\mathrm{p}=0.059)$ in load to failure tests.
\end{abstract}

Conclusion: Thanks to its high mechanical strength and early mobilization capability, distal femoral anatomical locking plate and IM nail combination might be a choice of treatment in complicated osteoporotic or distal femoral fractures from high-energy trauma in young adults.

Keywords: Biomechanics; distal femoral fractures; rigid fixation.

\section{öz}

Amaç: $\mathrm{Bu}$ çalışmada, kombine kullanımlarının tespit stabilizasyonunun güvenliğini artırdığı hipotezinden yola çıkılarak intramedüller (İM) çivi ve anatomik kilitli plağın mekanik özellikleri bir kemik modelinde araştırıldı.

Gereç ve yöntemler: Çalışmada 21 sol distal femur kırığı modeli kullanıldı. Kemikler 3 eşit gruba ayrıldı. Grup 1 örnekleri distal femur anatomik kilitli plak ile yandan tespit edildi. Grup 2 örnekleri distal femur retrograd IM çivi ile tespit edildi. Grup 3 örnekleri hem distal femur anatomik kilitli plak hem distal femur retrograd İM çivi ile tespit edildi. Mekanik testlerde aksiyel yüklenme değişimleri, torsiyon açıları ve kırılmaya kadar yüklenme değerleri ölçülerek gruplar arası karşılaştırıldı.

Bulgular: Grup 1'e göre grup 2 aksiyel yüklenme testlerinde göreceli olarak daha dayanıklı $(\mathrm{p}=0.225)$, kırılmaya kadar yüklenme testlerinde anlamlı şekilde daha dayanıklı $(\mathrm{p}=0.048)$ idi. Torsiyonel yüklenme testlerinde grup 1 grup 2'ye göre göreceli olarak daha dayanıklı $(\mathrm{p}=0.949)$ idi. Aksiyel $(\mathrm{p}=0.001)$, torsiyonel $(\mathrm{p}=0.012)$ yüklenme testleri ve kırılmaya kadar yüklenme testlerinde grup 3 grup 1'den anlamlı şekilde daha dayanıklı idi $(\mathrm{p}=0.008)$. Grup 2'ye göre grup 3 aksiyel $(\mathrm{p}=0.003)$, torsiyonel $(\mathrm{p}=0.008)$ yüklenme testlerinde anlamlı olarak, kırılmaya kadar yüklenme testlerinde $(\mathrm{p}=0.059)$ göreceli olarak daha dayanıklı idi.

Sonuç: Yüksek mekanik kuvveti ve erken mobilizasyon imkanı ile distal femur anatomik kilitli plak ve İM çivi kombinasyonu karmaşık osteoporotik veya genç erişkinlerde yüksek enerjili travma kaynaklı distal femur kırıklarında tercih edilen bir tedavi olabilir.

Anahtar sözcükler: Biyomekanik; distal femur kırıkları; rijit tespit.

- Received: September 01, 2014 Accepted: January 27, 2015

- Correspondence: Onur BaşCı, MD. Dokuz Eylül Üniversitesi Tıp Fakültesi Ortopedi ve Travmatoloji Anabilim Dalı, 35210 Alsancak, Izmir, Turkey Tel: +90 533 - 3179950 Fax: +90 232 - 4123351 e-mail: dronurbasci@gmail.com 
Distal femoral fractures compromise of $4-6 \%$ of all femoral fractures ${ }^{[1,2]}$ and more than $50 \%$ occurs in the elderly. ${ }^{[3,4]}$ High-energy trauma increases fracture incidence and complexity. ${ }^{[3,5]}$ Fractures in elderly patients are challenging in orthopedic trauma surgery. ${ }^{[6,7]}$

Studies have shown that internal fixation devices provide superior outcome as compared to closed methods allowing early mobilization by providing stability ${ }^{[8-11]}$ Among surgical methods, particularly intramedullary (IM) nails have been successful compared to side plates with decreased intraoperative blood loss, operating time, and hospital stay. ${ }^{[12-14]}$ Intramedullary nails are specifically suitable to type A fracture patterns. ${ }^{[15]}$ Also, a recent biomechanical study has demonstrated decreased micro-displacement in a retrograde IM nail versus two common plate implants. ${ }^{[16]}$ Distal femoral fractures are typically complex with comminution, bone quality may be poor or prosthesis may be present. The problem in majority of cases is not the soft tissue or the fracture type but the osteoporotic bone quality, which causes implant insufficiency and further union problems. ${ }^{[7]}$

Many biomechanical studies have investigated the effects of various implants on distal femoral fracture models. However, to our knowledge, no study was conducted on combined usage of retrograde femoral nailing and distal femoral anatomical plate regarding rigid fixation in the osteoporotic bone.

It was hypothesized that usage of IM nailing in combination with a locking anatomical plate provides safe stability allowing fixation in osteoporotic distal femoral fractures. Therefore, in this study, we aimed to investigate mechanical properties of IM nailing and anatomical locking plate in a bone model based on the hypothesis that their combined usage increases safety of fixation stabilization.

\section{MATERIALS AND METHODS}

Twenty-one left femurs (Left $4^{\text {th }}$ Generation Composite Femur, Sawbones, Malmö, Sweden) were used in the study. To mimic an extra-articular supracondylar femoral fracture (Type 33-A3, AO classification), a $10 \mathrm{~mm}$ gap was cut parallel to the knee base line, $65 \mathrm{~mm}$ proximal to the distal end of the femur by the aid of a surgical reciprocating saw. ${ }^{[16,17]}$ All specimens were prepared by the same two orthopedic surgeons. The standard technique for plate fixation and retrograde distal femoral nailing was performed. Osteotomy provided a noncontact situation, allowing for isolated testing of the implant combinations.
Three groups of implant constructs were tested. Group 1 specimens were fixed laterally by an anatomical distal femoral locking plate (Medtip Medical Device Company A.S., Turkey); group 2 specimens were fixed with retrograde distal femoral IM nail (Medtip Medical Device Company A.S., Turkey); and group 3 specimens were fixed with both anatomical distal femoral locking plate and retrograde distal femoral IM nail. In this group, the IM nail was locked proximally and distally by one interlocking screw for each and the plate was placed laterally inserting the screws anterior or posterior to the IM nail when intersected.

All the tests were performed with a mechanical test machine (AG-IS 10 kN, Shimadzu, Kyoto, Japan). The femoral bone models were fixed to the load cell of the test machine. In all of the tests, the alterations in axial, and torsional angles, and load to failure values were recorded (Figure 1). The bone-implant constructs were tested under axial loading with the femoral heads which were potted and fixed. $1000 \mathrm{~N}$ for 5000 cycles at $3 \mathrm{~Hz}$ were applied while simultaneously recording the vertical displacement and the strain. ${ }^{[17]}$

Torsion test was carried out with servo sync torque machine (SQM132, $245 \mathrm{Nm} 100 \mathrm{rpm}$, Turkey). The torsion tests were conducted in the displacement control mode with a maximum moment of $4.5 \mathrm{Nm}$ in both directions; the premoment was $0 \mathrm{Nm}$ and the

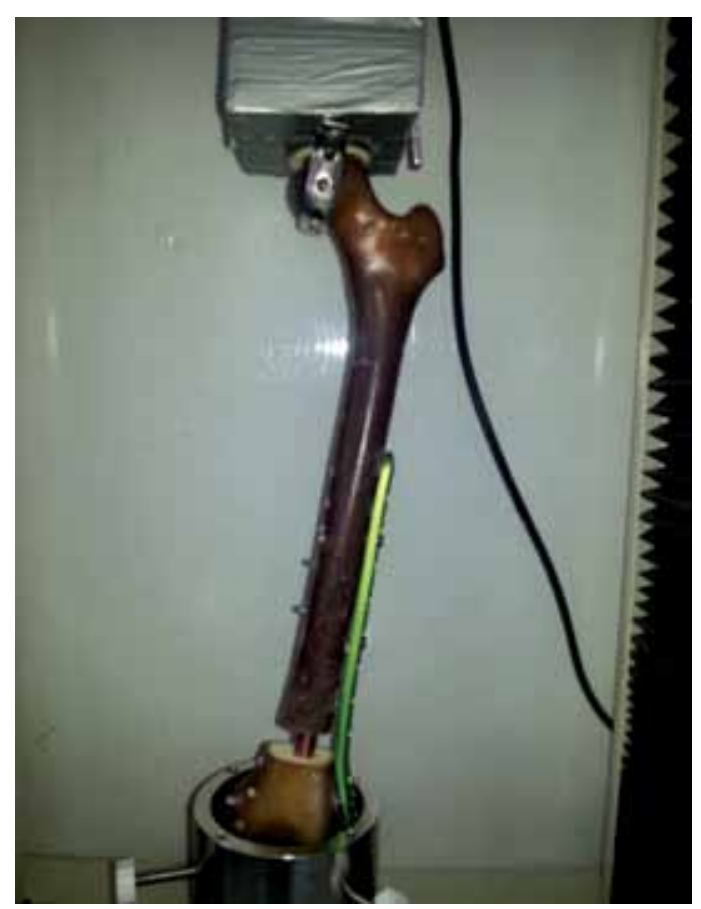

Figure 1. Mechanical testing set-up. 
test velocity was $0.3 \%$. The testing cycle was applied from 0 to $4.5 \mathrm{Nm}$. Torque versus the degree of angle deformation values were recorded. Following torsional testing, static external rotation was applied to failure, at a rate of $1 \mathrm{Nm} / \mathrm{s}$, to determine the ultimate torsional strength of the constructs (Figure 2 and 3).

Axial and torsion tests were repeated three times for each specimen to ensure reproducibility of the results. All tests were performed within the elastic behavior limits of the construct; the loaddeflection data did not show any sign of plastic or permanent deformation for any of the constructs in any orientation. The testing was performed in the same order for each sample. The statistical analysis was conducted with Kruskal-Wallis nonparametric ANOVA test by using SPSS for Windows version 15.0 software program (SPSS Inc., Chicago, IL, USA).

\section{RESULTS}

There were no fixation failures during axial or torsional stiffness testing within the elastic behavior limits. The average displacement values in the axial loading in group 1, group 2 and group 3 were $1.96 \mathrm{~mm}$ (range 1.43-2.56), $1.62 \mathrm{~mm}$ (range 1.07-2.11), and $0.86 \mathrm{~mm}$ (range 0.56-1.15), respectively. Regarding the torsional measurements, the mean torque values were $1.66 \mathrm{Nmm}$ (range 1.33-2.56), $1.72 \mathrm{Nmm}$ (range 1.16-2.11) and $0.96 \mathrm{Nmm}$ (range 0.87-1.05) in group 1, group 2 and group 3, respectively. The mean load to failure value was $4030 \mathrm{~N}$ (range 2981-5423) in group 1, $5549 \mathrm{~N}$ (range 4184-6615) in group 2, and $7466 \mathrm{~N}$ (range: 6835-8028) in group 3.

Group 2 was relatively superior to group 1 in terms of axial stability $(\mathrm{p}=0.225)$, and significantly more resistant in load to failure tests $(\mathrm{p}=0.048)$ while group 1 was relatively superior in terms of torsional stability $(p=0.949)$. Regarding axial, torsional load and load to failure tests, group 1 had significantly lower displacement values compared to group 3 ( $\mathrm{p}=0.001, \mathrm{p}=0.012, \mathrm{p}=0.008$; respectively). Compared to group 2, group 3 significantly more resistant in axial, torsional load tests, and relatively more resistant in load to failure tests $(\mathrm{p}=0.003, \mathrm{p}=0.008$, $\mathrm{p}=0.059$; respectively) (Table I).

\section{DISCUSSION}

This study investigated two different implants for the treatment of distal femoral fractures with special attention to the combined usage of both IM nailing and anatomical distal femoral fixation. Our results showed that IM nailing revealed a more stable construct compared to plate fixation in terms of axial and torsional loading and load to failure testing. However, combined usage of both implants provided an even more stable construct.

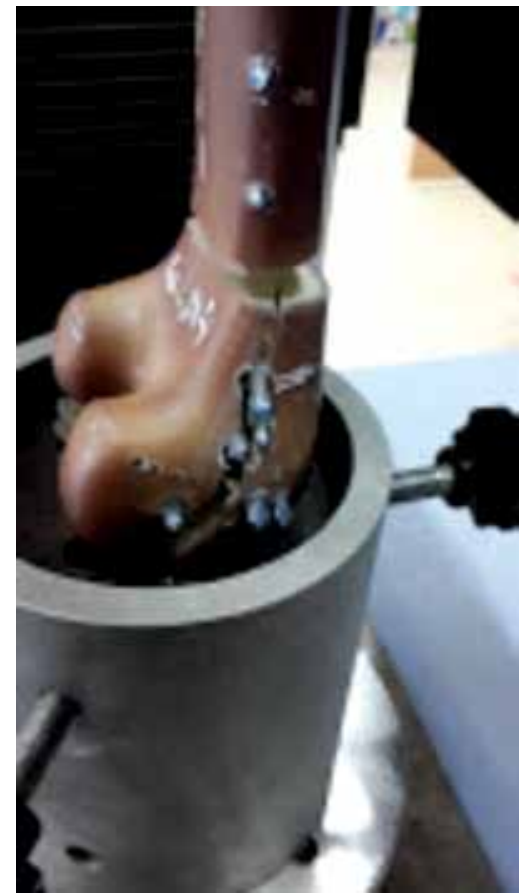

Figure 2. Failure appearance on sagittal plane after load to failure tests.

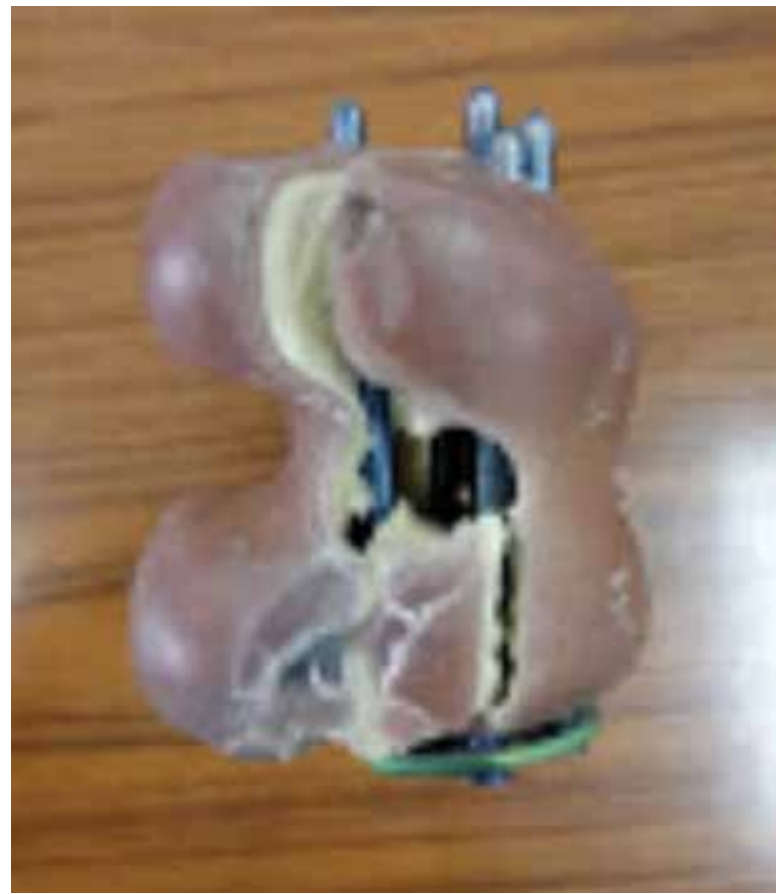

Figure 3. Failure appearance on axial plane after load to failure tests. 
TABLE I

$P$ values on Kruskal-Wallis nonparametric tests

\begin{tabular}{lccc}
\hline & $\begin{array}{c}\text { Axial } \\
\text { load }\end{array}$ & $\begin{array}{c}\text { Torsional } \\
\text { load }\end{array}$ & $\begin{array}{c}\text { Load to } \\
\text { failure }\end{array}$ \\
\hline Plate vs. IMN & 0.225 & 0.949 & 0.048 \\
Plate vs. plate + IMN & 0.001 & 0.012 & 0.008 \\
IMN vs. plate + IMN & 0.003 & 0.008 & 0.059 \\
\hline
\end{tabular}

Internal fixation of distal femoral fractures has been acknowledged to be superior over nonoperative treatment, but these fractures are challenging regarding implant and technical decision. ${ }^{[8-10]}$ The axial stiffness of the plated constructs is another clinical concern. Hence, delayed union and even nonunion of plated distal femoral fractures have been reported, particularly in cases where there was no medial cortical support. ${ }^{[18-20]}$ These adverse events have been attributed to poor axial stiffness permitting movement in the fracture gap. If the medial metaphyseal buttress is missed, the fracture might fall into varus before healing. For this, Sanders et al. ${ }^{[21]}$ have recommended double-plating techniques for fixation. However, although the authors have had good results with the double-plating technique, the surgery requires disruption of the medial and lateral soft tissues to achieve fixation.

There are a number of clinical articles regarding the role and efficacy of retrograde nailing in distal femoral fractures. ${ }^{[22-25]}$ In a systematic review of the literature by Papadokostakis et al., ${ }^{[2]}$ it was concluded that retrograde IM nailing was a reliable treatment method with less complications for distal femoral fractures, while similar judgments were made by Handolin et al. ${ }^{[25]}$ Retrograde IM nails have been shown to achieve good results in osteoporotic bone as well. ${ }^{[22,23]}$ The study of Zlowodzki et al. ${ }^{[26]}$ discussed that Less Invasive Stabilization System provided improved distal fixation compared to the retrograde nail in osteoporotic bones because of higher axial loads, load to failure and a lower incidence of fixation failure. In addition, displacement at the fracture site was lower.

Studies reported in the literature, which used artificial bones (the cortical bone with a density of $1.64 \mathrm{~g} / \mathrm{cm}^{3}$ ) for axial/torsional loading and modeling the same fracture type, supported our results, agreeing that plating provides greater torsional stability, whereas IM devices show greater axial strength. ${ }^{[11,26-29]}$ Regarding axial stiffness of plate constructs, the literature shows a range from $10 \%$ to $25 \%$ of axial stiffness achieved with IM nails. ${ }^{[30]}$
Sufficient implant anchorage is a challenge particularly in the treatment of osteoporotic distal femoral fractures. Fixation failures are common in osteoporotic fractures and better clinical results are achieved as the construct is more stable. ${ }^{[31]}$ However, rigid internal fixation of osteoporotic fractures in elderly patients is difficult due to degree of comminution and poor bone stock. ${ }^{[32,33]}$ Thus, the idea of application of retrograde IM nail supported by an anatomical distal femoral locking plate laterally seems logical in terms of biomechanical stability. In addition, using minimally invasive techniques for the plate application may support biological union. In our study, the IM nail combined with plate fixation group had the least gap motion and the highest stiffness. The stiffness of the gap depended on the bone-implant construct to resist the micromotion across the gap. The magnitude of differences demonstrated in this study may be clinically relevant.

We think that combining IM nailing with plate augmentation increases the advantages of these two techniques in fracture fixation, while their potential complications and disadvantages may be avoided. The IM nail will serve as a load sharing device, neutralizing the shearing forces on the fracture, and maintaining the general alignment of both the fracture and the limb. The plate augmentation may control continuous excess motion at the site of complex, comminuted unstable fractures, and thus provide stability of the fracture.

Clinically, although delay in fracture healing is not always obvious, the decreased healing capacity in osteoporosis is reflected in a dramatically increased rate of failure of implant fixation. ${ }^{[34]}$ When it is considered that the main objective of surgery in elderly patients is early ambulation and achieving a stable painless weight-bearing limb with preservation of knee function, the low axial loading capacity of the plate fixation and the low torsional loading capacity of the IM nail construct measured in our study might have a negative influence on the early immobilization process.

Our biomechanical study had some other limitations: (i) the simplified test set-up did not simulate soft-tissue forces such as capsules, ligaments and muscles but represents an anatomical loading condition, ${ }^{[35,36]}$ (ii) a total of 5,000 cycles per loading step was not truly representative for a postoperative loading pattern, and (iii) the synthetic femoral bones were chosen as they consistently simulate the characteristics of young bone. While this aided to eliminate the variable data obtained from cadaveric 
specimens and was safer, it limited our study by not resembling an osteoporotic bone.

In conclusion, we demonstrated that combined usage of distal femoral anatomical locking plate with IM nails is important for the stabilization of osteoporotic distal femoral fractures in terms of both primary biomechanical stiffness and strength of the constructs. Further studies are required using osteoporotic human cadaver specimen to show the benefit of the implants in human bone, while secondary clinical trials are recommended to demonstrate better outcomes and patient benefits.

\section{Declaration of conflicting interests}

The authors declared no conflicts of interest with respect to the authorship and/or publication of this article.

\section{Funding}

The authors received no financial support for the research and/or authorship of this article.

\section{REFERENCES}

1. Kolmert L, Wulff K. Epidemiology and treatment of distal femoral fractures in adults. Acta Orthop Scand 1982;53:957-62.

2. Martinet O, Cordey J, Harder Y, Maier A, Bühler M, Barraud GE. The epidemiology of fractures of the distal femur. Injury 2000;31:62-3.

3. Arneson TJ, Melton LJ, Lewallen DG, O'Fallon WM. Epidemiology of diaphyseal and distal femoral fractures in Rochester, Minnesota, 1965-1984. Clin Orthop Relat Res 1988;234:188-94.

4. Orozco R, Sales M, Videla M. Atlas of Internal Fixation: Fractures of Long Bones. Barcelona: Springer-Verlag; 1998.

5. Henry SL, Trager S, Green S, Seligson D. Management of supracondylar fractures of the femur with the GSH intramedullary nail: preliminary report. Contemp Orthop 1991;22:631-40.

6. Gül O, Atik OS, Erdoğan D, Göktaş G, Elmas C. Transmission and scanning electron microscopy confirm that bone microstructure is similar in osteopenic and osteoporotic patients. Eklem Hastalik Cerrahisi 2013;24:126-32.

7. Atik OS. Second hip fracture in elderly patients. Eklem Hastalik Cerrahisi 2014;25:125.

8. Butt MS, Krikler SJ, Ali MS. Displaced fractures of the distal femur in elderly patients. Operative versus non-operative treatment. J Bone Joint Surg [Br] 1996;78:110-4.

9. Forster MC, Komarsamy B, Davison JN. Distal femoral fractures: a review of fixation methods. Injury 2006;37:97-108.

10. Healy WL, Brooker AF Jr. Distal femoral fractures. Comparison of open and closed methods of treatment. Clin Orthop Relat Res 1983;174:166-71.

11. David SM, Harrow ME, Peindl RD, Frick SL, Kellam JF. Comparative biomechanical analysis of supracondylar femur fracture fixation: locked intramedullary nail versus 95-degree angled plate. J Orthop Trauma 1997;11:344-50.

12. Gellman RE, Paiement GD, Green HD, Coughlin RR.
Treatment of supracondylar femoral fractures with a retrograde intramedullary nail. Clin Orthop Relat Res 1996;332:90-7.

13. Henry SL, Seligson D. Management of supracondylar fractures of the femur with the GSH supracondylar nail: the percutaneous technique. Techniques in Orthopaedics 1993;9:189-94.

14. Iannacone WM, Bennett FS, DeLong WG Jr, Born CT, Dalsey RM. Initial experience with the treatment of supracondylar femoral fractures using the supracondylar intramedullary nail: a preliminary report. J Orthop Trauma 1994;8:322-7.

15. Sears BR, Ostrum RF, Litsky AS. A mechanical study of gap motion in cadaveric femurs using short and long supracondylar nails. J Orthop Trauma 2004;18:354-60.

16. Heiney JP, Barnett MD, Vrabec GA, Schoenfeld AJ, Baji A, Njus GO. Distal femoral fixation: a biomechanical comparison of trigen retrograde intramedullary (i.m.) nail, dynamic condylar screw (DCS), and locking compression plate (LCP) condylar plate. J Trauma 2009;66:443-9.

17. Marti A, Fankhauser C, Frenk A, Cordey J, Gasser B. Biomechanical evaluation of the less invasive stabilization system for the internal fixation of distal femur fractures. J Orthop Trauma 2001;15:482-7.

18. Schütz M, Müller M, Krettek C, Höntzsch D, Regazzoni P, Ganz R, et al. Minimally invasive fracture stabilization of distal femoral fractures with the LISS: a prospective multicenter study. Results of a clinical study with special emphasis on difficult cases. Injury 2001;32:48-54.

19. Schütz M, Müller M, Regazzoni P, Höntzsch D, Krettek C, Van der Werken C, et al. Use of the less invasive stabilization system (LISS) in patients with distal femoral (AO33) fractures: a prospective multicenter study. Arch Orthop Trauma Surg 2005;125:102-8.

20. Fankhauser F, Gruber G, Schippinger G, Boldin C, Hofer $\mathrm{HP}$, Grechenig W, et al. Minimal-invasive treatment of distal femoral fractures with the LISS (Less Invasive Stabilization System): a prospective study of 30 fractures with a follow up of 20 months. Acta Orthop Scand 2004;75:56-60.

21. Sanders R, Swiontkowski M, Rosen H, Helfet D. Doubleplating of comminuted, unstable fractures of the distal part of the femur. J Bone Joint Surg Am 1991;73:341-6.

22. Armstrong R, Milliren A, Schrantz W, Zeliger K. Retrograde interlocked intramedullary nailing of supracondylar distal femur fractures in an average 76-year-old patient population. Orthopedics 2003;26:627-9.

23. Gynning JB, Hansen D. Treatment of distal femoral fractures with intramedullary supracondylar nails in elderly patients. Injury 1999;30:43-6.

24. Papadokostakis G, Papakostidis C, Dimitriou R, Giannoudis PV. The role and efficacy of retrograding nailing for the treatment of diaphyseal and distal femoral fractures: a systematic review of the literature. Injury 2005;36:813-22.

25. Handolin L, Pajarinen J, Lindahl J, Hirvensalo E. Retrograde intramedullary nailing in distal femoral fractures--results in a series of 46 consecutive operations. Injury 2004;35:517-22.

26. Zlowodzki M, Williamson S, Cole PA, Zardiackas LD, Kregor PJ. Zlowodzki M, Williamson S, Cole PA, Zardiackas LD, Kregor PJ. J Orthop Trauma 2004;18:494-502.

27. Firoozbakhsh K, Behzadi K, DeCoster TA, Moneim MS, Naraghi FF. Mechanics of retrograde nail versus plate fixation for supracondylar femur fractures. J Orthop Trauma 1995;9:152-7. 
28. Koval KJ, Kummer FJ, Bharam S, Chen D, Halder S. Distal femoral fixation: a laboratory comparison of the 95 degrees plate, antegrade and retrograde inserted reamed intramedullary nails. J Orthop Trauma 1996;10:378-82.

29. Meyer RW, Plaxton NA, Postak PD, Gilmore A, Froimson MI, Greenwald AS. Mechanical comparison of a distal femoral side plate and a retrograde intramedullary nail. J Orthop Trauma 2000;14:398-404.

30. Ito K, Grass R, Zwipp H. Internal fixation of supracondylar femoral fractures: comparative biomechanical performance of the 95-degree blade plate and two retrograde nails. J Orthop Trauma 1998;12:259-66.

31. Schandelmaier P, Farouk O, Krettek C, Mannss J, Tscherne $\mathrm{H}$. Biomechanik von Femurverriegelungsmarknageln im Knochen-Implantat-Verbund. Langenbecks Arch Chir 1997;382:167-72. [Abstract]
32. Schatzker J, Lambert DC. Schatzker J, Lambert DC. Clin Orthop Relat Res 1979;138:77-83.

33. Moore TJ, Watson T, Green SA, Garland DE, Chandler RW. Complications of surgically treated supracondylar fractures of the femur. J Trauma 1987;27:402-6.

34. Barrios C, Broström LA, Stark A, Walheim G. Healing complications after internal fixation of trochanteric hip fractures: the prognostic value of osteoporosis. J Orthop Trauma 1993;7:438-42.

35. Taylor SJ, Walker PS. Forces and moments telemetered from two distal femoral replacements during various activities. J Biomech 2001;34:839-48.

36. Taylor SJ, Walker PS, Perry JS, Cannon SR, Woledge R. The forces in the distal femur and the knee during walking and other activities measured by telemetry. J Arthroplasty 1998;13:428-37. 